\title{
SEQUENCE DIVERSITY IN THE COAT PROTEIN OF SCMV INFECTING MAIZE AND SORGHUM IN BRAZIL
}

\author{
ISABEL REGINA PRAZERES DE SOUZA ${ }^{1}$, FABIAN GIOLITTI ${ }^{2}$, \\ NEWTON PORTILHO CARNEIRO ${ }^{1}$, SERGIO LUIS LENARDON², \\ ELIZABETH DE OLIVEIRA ${ }^{1}$, ELIANE APARECIDA GOMES ${ }^{1}$, \\ ROBERTO WILLIANS NODA ${ }^{1}$ e FRANCISCO ADRIANO DE SOUZA ${ }^{1}$
}

\begin{abstract}
${ }^{1}$ Embrapa Milho e Sorgo, Sete Lagoas, MG, Brasil, isabel.prazeres@embrapa.br, newton.carneiro@embrapa.br, elizabeth.o.sabato@embrapa.br,eliane.aparecida@embrapa.br,roberto.noda@embrapa.br,francisco.adriano@embrapa.br, Corresponding author,E-mail: isabel.prazeres@embrapa.br

2IPAVE-CIAP-INTA, Córdoba, Argentina,giolitti.fabian@inta.gob.ar,lenardon.sergio@inta.gob.ar
\end{abstract}

Revista Brasileira de Milho e Sorgo, v.11, n.2, p. 120-136, 2012

\begin{abstract}
The "maize common mosaic", caused by potyvirus, is among the major virus diseases of this crop in Brazil. Although there were evidences indicating Sugarcane mosaic virus (SCMV) as the most common potyvirus species in maize (Zea mays L.) in Brazil, information about those species that infect sorghum plants [Sorghum bicolor (L.) Moench] are few. Leaves showing characteristic mosaic symptoms were collected from maize and sorghum and used in serological and sequencing analysis of the coat protein (CP) gene for potyvirus species identification. Amino acid (aa) analysis of the CP N-terminal sequence of our samples showed a different repeated sequence, a higher content of the dipeptide GT, and a 15 aa longer than the majority of the SCMV sequences used for comparisons. The Brazilian maize and sorghum potyviruses formed a monophyletic group, suggesting that they can be classified within a new SCMV strain. Studies using potyvirus CP gene sequencing from Brazilian sorghum potyvirus have been reported for the first time. Key words: coat protein, N-terminal, potyvirus, serological tests, Sorghum bicolor (L.) Moench, Sorghum sudanense, Sorghum verticilliflorum, Zea mays L.
\end{abstract}

\section{DIVERSIDADE DE SEQUÊNCIA DA PROTEÍNA CAPSIDIAL DE SCMV INFECTANDO MILHO E SORGO NO BRASIL}

\begin{abstract}
RESUMO - O "mosaico comum do milho", causado por potyvirus, destaca-se entre as viroses mais importantes desta cultura. Embora existam evidências indicando Sugarcane mosaic virus (SCMV) como a espécie de potyvirus predominante em milho (Zea mays L.) com sintomas dessa virose no Brasil, poucas são as informações sobre as espécies de potyvirus infectando plantas de sorgo [Sorghum bicolor (L.) Moench]. Folhas de milho e de sorgo apresentando sintomas típicos de mosaico foram coletadas e utilizadas em análises sorológicas e de sequenciamento do gene da proteína capsidial para identificação da espécie de potyvirus. Análise da sequência de aminoácidos (aa) da região do N-terminal da proteína capsidial (CP) dessas amostras mostrou uma sequência repetida diferente, com elevado conteúdo do dipeptídeo GT e 15 aa maior que a maioria dos acessos utilizados para comparações. Os potyvirus infectando milho e sorgo, no Brasil, formam um grupo monofilético, sugerindo tratar-se de uma nova estirpe de SCMV. Estudos utilizando sequenciamento do gene da CP de potyvirus infectando sorgo no Brasil estão sendo relatados pela primeira vez. Palavras-chave: proteína capsidial, N-terminal, potyvirus, testes sorológicos, Sorghum bicolor (L.) Moench, Sorghum sudanense, Sorghum verticilliflorum, Zea mays L.
\end{abstract}

Versão impressa ISSN 1676-689X / Versão on line ISSN 1980-6477 http://www.abms.org.br 
The disease "maize common mosaic" caused by potyvirus is among the major virus diseases of this crop in Brazil (Waquil et al., 1996; Souza et al., 2005; Gonçalves et al., 2011). Six potyviruses species have been identified worldwide, causing mosaic symptoms in a variety of grain crops and grasses, including: Sugarcane mosaic virus (SCMV), Sorghum mosaic virus (SrMV), Maize dwarf mosaic virus (MDMV), Johnsongrass mosaic virus (JGMV) (Shukla et al., 1994), Zea mosaic virus (ZeMV) (Sheifers et al., 2000), and Pennisetum mosaic virus (PenMV) (Denget al., 2008). There are evidences that SCMV is the most common virus causing mosaic in maize (Zea mays L.) in Brazil (Melo, 2000; Melo et al., 2000; Souza et al., 2005; Gonçalves et al., 2011). However, information about the potyvirus species infecting sorghum [Sorghum bicolor (L.) Moench] in Brazil are few.

Potyvirus particles are flexuous rods, 680$900 \mathrm{~nm}$ long and 11-15 $\mathrm{nm}$ wide with a genome consisting of single stranded, positive sense RNA (Shukla et al., 1991). Members of this genus infect several cultivated and weed Poaceae species (Shukla et al., 1994; Almeida et al., 2000). The potyviruses are transmitted in a nonpersistent manner by many aphid species and the most efficient vector in maize crop is Rhopalosiphum maidis L. (Hemiptera: Aphididae) (Edwardson \& Christie, 1991).

One of the factors that influence the dissemination of this virus is the overlapping cycles of maize crop. In Brazil, the second maize cropping season (known as "safrinha"), which is sown from January to March (Cruz et al., 2010), the off-season maize crop cultivation (under irrigation), and the main growing season are responsible for the maize crop overlapping (Waquil et al., 1996; Gonçalves et al., 2007a). This condition, associated with the large number of hosts
(Edwardson \& Christie, 1991), contributes to the maintenance of the inoculum in the field.

Studies to identify the potyvirus infecting maize in Brazil are recent and have shown through $\mathrm{CP}$ gene sequencing that SCMV was present and had a higher identity with SCMV-MDB, 86.3\% (Almeida et al., 2000; Souza et al., 2005; Gonçalves et al., 2011), suggesting a new strain. SCMV-MDB is an American strain of SCMV, formerly classified as MDMV-B (Frenkel et al., 1991).

The objectives of this study were (i) to identify by serological methods and $\mathrm{CP}$ gene sequencing the potyvirus species causing mosaic symptoms in maize and sorghum in Brazil, and (ii) to analyze the $\mathrm{N}$-terminal amino acid sequence of the CP gene.

\section{Material and Methods}

\section{Plant material}

Leaves showing characteristic mosaic symptoms, small irregular chlorotic areas interspersed with small irregular green areas, were collected from maize and sorghum, in Brazil, in 2004. Samples from maize cultivars were identified as follows: 01, 02, and 06; from S. bicolor cultivars: 08, 09, and 13, from cultivars originated from the crossing of Sorghum bicolor $x$ Sorghum sudanense: 10 and 11; and from Sorghum verticilliflorum: 14. Sample 08 was from Jardinópolis, São Paulo state, Brazil, and the others from Sete Lagoas, Minas Gerais state, Brazil.

\section{Serological tests}

Kits from LOEWE Phytodiagnostica (Sauerland, Germany) were used for the DAS-ELISA 
tests: SCMV (MDMV-B), MDMV-A, SrMV, JGMV and antisera for MDMV-Arg (Lenardon \& Giolitti 1999) and SCMV-Arg (Lenardon \& Giolitti, 2004) were obtained from IFFIVE-INTA (Argentina) and SCMV-USA (kindly provided by D.T. Gordon, Department of Plant Pathology, Ohio State University).

Three hundred milligrams of lyophilized leaf tissue from each of the samples showing mosaic symptoms plus four positive and two negative controls were used for analysis following the protocol described by Clark \& Adams (1977). Lyophilized tissues of samples and controls were hydrated for $4 \mathrm{~h}$ in the extraction PBS buffer $\left(3 \mathrm{mM} \mathrm{KCl}, 3 \mathrm{mM} \mathrm{NaN}_{3}\right.$, $8 \mathrm{mM} \mathrm{Na}_{2} \mathrm{HPO}_{4}, 1 \mathrm{mM} \mathrm{NaH} \mathrm{PO}_{4}, 0.13 \mathrm{M} \mathrm{NaCl}, \mathrm{pH}$ 6.8) containing $2 \%$ PVP 40.000 and $0.05 \%$ Tween 20 at $4{ }^{\circ} \mathrm{C}$ and ground 1:10 (wt vol ${ }^{-1}$ ). The homogenates were then centrifuged at 2,000 $\mathrm{g}$ at $4{ }^{\circ} \mathrm{C}$ for $5 \mathrm{~min}$. Microtiter plates (Nunc, Rochester, NY, USA) were coated with $100 \mu \mathrm{l}$ of corresponding IgGs dilutions (IgGs Kits: 1/200, MDMV-Arg: 1/2000, SCMV-Arg and SCMV-USA: 1/500) in carbonate buffer $(0.05$ $\mathrm{M} \mathrm{Na}{ }_{2} \mathrm{CO}_{3} / \mathrm{NaHCO}_{3}, \mathrm{pH}$ 9.6) and incubated for 4 $\mathrm{h}$ at $37^{\circ} \mathrm{C}$. Then, $100 \mu \mathrm{l}$ of each supernatant were loaded to each plate in duplicate wells and incubated overnight at $4{ }^{\circ} \mathrm{C}$. Plates were washed six times for ten seconds each with $200 \mu \mathrm{l} /$ well of PBS plus $0.05 \%$ Tween 20, in a microplate washer (TECAN 96 PW, Männedorf, Switzerland). Alkaline phosphataseconjugated IgGs were diluted in extraction buffer plus $0.2 \%$ egg albumin (conjugated IgGs Kits: $1 / 200$, MDMV-Arg: 1/2000, SCMV-Arg: 1/500, and SCMVUSA: 1/1000). Then, each dilution was loaded in the corresponding plate $\left(100 \mu 1 \mathrm{well}^{-1}\right)$ and incubated for $4 \mathrm{~h}$ at $37{ }^{\circ} \mathrm{C}$. Finally, to this was added $100 \mu 1$ well $^{-1}$ of a solution of $p$-nitrophenyl phosphate, at $0.6 \mathrm{mg}$ $\mathrm{ml}^{-1}$ (Sigma-Aldrich, St Louis, MO, USA), in $10 \%$ diethanolamine, $\mathrm{pH}$ 9.8, and the plate was incubated at $37^{\circ} \mathrm{C}$. Absorbance was determined at $405 \mathrm{~nm}$ by an ELISA-reader (Dynex MRX II, Chantilly, VA, USA). Values greater than the mean of the healthy controls plus three times the standard deviation were considered as positive.

\section{RT-PCR and electrophoresis}

Samples that reacted positively in the DASELISA were tested by Direct Binding-RT-PCR (Rowhani et al., 1995; Suehiro et al., 2005) using specific primers pairs for JGMV, MDMV-Argentina, SCMV-Argentina, and SCMV-Brazil (Table 1). These primers amplify the coat protein and part of the nuclear inclusion $b$ protein. One hundred milligrams of the lyophilized samples, positive and negative controls, were ground with liquid nitrogen and ressuspended $1 / 10$ in DAS-ELISA carbonate buffer, containing $2 \%$ PVP 40,000 and $0.1 \% \mathrm{Na}_{2} \mathrm{SO}_{3}$ and centrifuged $5 \mathrm{~min}$ at $2.000 \mathrm{~g}$ and $4{ }^{\circ} \mathrm{C}$. Thirty $\mu \mathrm{l}$ aliquots of plant extract supernatant were placed into $0.5 \mathrm{ml}$ micro-centrifuge sterile tubes and incubated overnight at $4{ }^{\circ} \mathrm{C}$. After three washes with ELISA washing buffer, one-step RT-PCR was carried out using the Access RT-PCR System (Promega, Wisconsin, USA) following the manufacturer's instructions and using $0.25 \mu \mathrm{M}$ of each corresponding primer. The RT-PCR was performed in a T3 Thermo block (Whatman Biometra, Göttingen, Germany); in all cases the reactions were carried out for $45 \mathrm{~min}$ at $48^{\circ} \mathrm{C}$, after which the tubes were heated for $4 \mathrm{~min}$ to $94{ }^{\circ} \mathrm{C}$. The following PCR reactions were performed: JGMV $\left(5\right.$ cycles of $94^{\circ} \mathrm{C}$ for $30 \mathrm{~s}, 57^{\circ} \mathrm{C}$ for $30 \mathrm{~s}$, and $68^{\circ} \mathrm{C}$ for $1 \mathrm{~min} ; 30$ cycles of $94^{\circ} \mathrm{C}$ for $30 \mathrm{~s}, 55^{\circ} \mathrm{C}$ for $30 \mathrm{~s}$, and $68^{\circ} \mathrm{C}$ for $1 \mathrm{~min}$ ), and MDMV-Arg, SCMV-Arg, and SCMV-Brazil (40 cycles of $94{ }^{\circ} \mathrm{C}$ for $30 \mathrm{~s}, \mathrm{X}^{\circ} \mathrm{C}$ for $30 \mathrm{~s}$, and $68^{\circ} \mathrm{C}$ for 
$1 \mathrm{~min}$ ), where $\mathrm{X}$ is $55^{\circ} \mathrm{C}$ for MDMV-Arg, $51{ }^{\circ} \mathrm{C}$ for SCMV-Arg and $48{ }^{\circ} \mathrm{C}$ for SCMV-Brazil. The PCR reactions were followed by one step of $7 \mathrm{~min}$ at 68 ${ }^{\circ} \mathrm{C}$ and kept at $4{ }^{\circ} \mathrm{C}$ until they were removed from the thermal cycler. PCR products were electrophoresed in $1.4 \%$ agarose gel, stained with ethidium bromide and the image visualized in the Bio-Rad Universal Hood II Gel Imager (USA, Hercules, CA).
BLASTN algorithm (Altschul et al., 1990) was used to search at NCBI sequence databases (www.ncbi. nlm.nih.gov) in order to confirm sequence identities.

The DNA sequences were deposited to the GenBank in December 2005 under the accession numbers DQ315489 (Sample 01), DQ315490 (Sample 02), DQ315491 (Sample 06), DQ315492 (Sample 08), DQ315493 (Sample 09), DQ315494 (Sample10),

TABLE 1. Primer pairs sequence for RT-PCR of distinct potyviruses.

\begin{tabular}{cccc}
\hline Potyvirus & Primer name & Primer sequence 5' -3' $^{\prime}$ & Reference \\
\hline \multirow{2}{*}{ JGMV* $^{*}$} & JG5 $^{\prime}$ & AGAGATGTACAAGAACGCCATCGC & Lenardon \\
& JG3 $^{\prime}$ & CATCCTTTAACGTCAGATCGACGG & \& Giolitti (2004) \\
SCMV-Arg* & SC5' & TTACAACGAAGATGTTTTCC & Giolitti \\
& SC3' & CTGAAATAGTAAATACGAGG & et al. (2005) \\
MDMV-Arg* & MD5' & ACGACAATTCTTTGACGATCTTCC & Lenardon \\
& MD3' & CCTCACTCACTTGCAGACATAGTAGG & \& Giolitti (2004) \\
SCMV-Brazil & MDMV2 & GTATTCCATCAGTCGGGAACTG & Melo (2000); \\
& MDMV3 & ACGAGGTAAAACCTCAC & Resende et al. (2004) \\
\hline
\end{tabular}

*Primer pairs JG5'/JG3', MD5'/MD3', SC5'/SC3' had been previously designed by Giolitti (co-author, personal communication), based on the sequences of the NCBI, respectively, JGMV-MDO (U07217), MDMV-Argentina (DQ973169), and SCMV-Argentina (DQ973170).

\section{Cloning and}

\section{Sequencing the dsDNA}

The resulting $1 \mathrm{~Kb}$ PCR products were purified using the QIAquick Gel Extraction Kit (Qiagen, Hilden, Germany) and cloned into the vector TOPO 2.1 (Invitrogen, USA) according to manufacturer's instructions. The cloned fragment was sequenced in both directions using the primers MDMV2 and MDMV3 and the ABI Prism ${ }^{\mathrm{TM}}$ BigDye $^{\mathrm{TM}}$ Terminator Cycle Sequencing Ready Reaction Kit (Applied Biosystems, Foster City, CA, USA) in an ABI PRISM 3100 Genetic Analyzer (Applied Biosystems).
DQ315495 (Sample 11), DQ315496 (Sample 13), and DQ315497 (Sample14).

\section{Alignment of the nucleotide and amino acid coat protein sequences}

From the NCBI on May 2011, we downloaded 347 DNA sequences of SCMV using the Taxonomy ID 12224. From those we selected 275 sequences that had the coat protein gene with a minimum length of $700 \mathrm{bp}$. These selected sequences were aligned with SeaView version 4.3.0 (Gouy et al., 2010), using ClustalW2 (Larkin et al., 2007). 
The length of the final alignment was adjusted to fit with the size of the sequences of the coat protein gene of the present work. The sequences of the accessions D00949 and A34976 were added representing the SCMV-MDB, along with six sequences of the outgroups (U07217_JGMV, DQ973169_MDMV from Argentina, U07216_MDMV-A, AF228693_ ZeMV, U57358_SrMV, and AY642590_PenMV). The alignment of the CP nucleotide sequence was used for phylogenetic tree reconstruction.

For comparisons of the N-terminal and core region of the $\mathrm{CP}$ the amino acid sequence of accessions from different countries and from Brazil was used, having maize or sugarcane as host. Amino acid CP alignments were performed using ClustalW2 (Larkin et al., 2007) implemented on SeaView package version 4 (Gouy et al., 2010).

\section{Phylogenetic Reconstruction}

Phylogenetic reconstruction from the $\mathrm{CP}$ nucleotide sequence was obtained using the alignment as described above. The tree was generated through SeaView package version 4 (Gouy et al., 2010) with the Neighbor-joining method using the Kimura 2-parameter model (Kimura, 1980) for distance estimation and bootstrap analyses with 1,000 replications. Cluster definitions were based on monophyletic groups from a fixed level indicated by the topology of the tree.

\section{Results}

\section{Serological Tests}

Serological tests of the samples with polyclonal antibodies against SrMV and MDMV-Arg did not show any reaction, except for its homologous virus controls. All the samples reacted with antibodies against SCMV (MDMV-B) and SCMV-Arg, but strongly reacted with the first one. Some of the samples (01, 02 and 06 from maize; 08 from sorghum) showed a weak reaction with antibodies against SCMV-USA. These three samples from maize $(01,02$ and 06) also presented a weak reaction with JGMV. Only sample 06 reacted with the MDMV-A antibody.

\section{Immunocapture RT-PCR}

Only the primers for SCMV-Brazil amplified a fragment of approximately $1 \mathrm{~Kb}$. All the other primers only amplified the homologous virus controls (Table 1). Comparisons of the amplified sequence showed the same amplified fragment of the $1072 \mathrm{bp}$, comprising part of the NIb (nt 1 to 11), all the CP (nt 12 to 998), and a small part of the 3'UTR (nt 999 to 1072) previously related by Melo (2000) and Resende et al. (2004).

\section{Alignment \\ of the N-terminal}

\section{amino acid sequence of the coat protein (CP)} and percentages of the dipeptides glycine/ threonine (GT) and glycine/serine (GS), (GT+GS), and amino acids T, S, and G

The deduced amino acid sequence of the variable $\mathrm{N}$-terminal end of the coat protein derived from the amplified fragment of the SCMV from maize and sorghum Brazilian samples was aligned with some of the available SCMV CP sequences from public databases (Figure 1). The total length of the Brazilian samples consisted of 328 aa, as GU474635 from Mexico and D00949 (SCMV-MDB) 
and A34976 from the USA. The majority of other accessions had a CP length of 313 aa. This difference is located in the length of the N-terminal with 15 aa residues in Brazilian maize and sorghum field isolates longer than the majority of the GenBank accessions from maize and sugarcane. The Brazilian accessions isolated from sugarcane (AY819716, AY819717, and AY819718) and one from maize (HQ342698) had an $\mathrm{N}$-terminal with, respectively, 15 and 5 aa residues less than our maize and sorghum samples. The coat protein of the Brazilian SCMV from maize and from sorghum samples and from the maize Brazilian accessions HQ342698, HQ439439, and HQ439440 presented the protease cleavage site $\mathrm{Q} / \mathrm{S}$ and from Brazilian sugarcane accessions -/A. N-terminal amino acid residues, from position 1 to 11 , were very conserved among all Brazilian samples and Brazilian maize accessions. Brazilian SCMV from maize and sorghum presented a duplicated dodecapeptide GTGTGATGGQAG, positions 40 to 51 and 57 to 68 , and partially replicated as an octopeptide GTGATGGQ, positions 82 to 89 (Figure 1). Some of the isolates showed GGT or GVT in the octopeptide sequence instead of GAT. In this case, the aa residue A was changed by $\mathrm{G}$ or $\mathrm{V}$, all of them being nonpolar with aliphatic $\mathrm{R}$ groups. Although the coat protein of the SCMV from Brazilian maize and sorghum samples and the accessions SCMV-MDB D00949, A34976, and GU474635 had the same length, the duplicated and partially repeated sequences in their amino termini, positions 34 to 49, 53 to 66 and 68 to 73 differ from our samples, have only GATGGQ in common, which is part of the repeated sequence in the position 53 to 66 . The four Brazilian sugarcane accessions presented the duplicated decapeptide QPPATGAAAQ at positions 18 to 27 and 31 to 40 and partially repeated as QPPTGGA at positions 48 to 54 .
Comparison of the core region of the deduced amino acid coat protein sequence, residues from position 74 or 89 to the 3' termini, of the GenBank accessions, and Brazilian samples was highly conserved, with identity ranging from 94 to $99 \%$ among them. Comparisons of the nucleotide sequence of the entire coat protein of the Brazilian samples showed identity ranging from 90 to $99 \%$ among them and from $85 \%$ to $91 \%$ in relation to the Brazilian maize isolate HQ342698, and from 90 to $96 \%$ for the isolates HQ439439 and HQ439440. The accessions SCMVMDB D00949, A34976, and GU474635 had identities varying from 85 to $87 \%$ when compared with these Brazilian maize and sorghum field isolates.

The percentage of the dipeptide GT in the N-terminal (Table 2) was higher for the Brazilian samples and for two of the three Brazilian maize accessions HQ439439 and HQ439440, varying from 10.23 to $14.77 \%$, positioned above the average, 7.36\%. The third accession (HQ342698) had the same amount of the dipeptides GT and GS, $8.43 \%$. Also for the $\mathrm{G}$ and $\mathrm{T}$ contents the Brazilian samples and Brazilian maize accessions showed the tendency for higher values, 36.36 to $42.05 \%$ and 19.32 to $26.14 \%$, respectively. Only accessions DQ647659 and DQ925429, from Thailand and Vietnam respectively, presented $G$ values higher than those. However, compared with the accessions having maize as host, the Brazilian samples presented the lowest values for the GS content, 1.14 to $3.41 \%$. These values were similar to those showed by Brazilian accessions having sugarcane as host, AY819716, AY819717, AY819718, and AY819719. These Brazilian sugarcane accessions showed values of the GT, GS and (GT+GS) contents, varying from 2.75 to $4.55 \%$, zero to $1.37 \%$ and 4.11 to $5.41 \%$ that were below the averages, respectively, $7.36,5.46$ and $12.83 \%$. 
TABLE 2. Percentages of the dipeptides GT and GS, (GT+GS), T, S, and G content in the N-terminal of the coat protein of the Brazilian samples and accessions from the Genbank. Accessions are the same from Figure 1. Hosts are identified by $\mathrm{Mz}=$ maize, $\mathrm{Sr}=$ sorghum, $\mathrm{Sgc}=$ sugarcane, followed by the country code. Original host and country, when not available at GenBank, were obtained from the references. The length of the N-terminal used for calculation of the contents was from the amino acid position 1 (one) up to that immediately before the QRDKDV sequence in the core region.

\begin{tabular}{|c|c|c|c|c|c|c|}
\hline \multirow{2}{*}{ Accessions } & \multicolumn{6}{|c|}{$\%$} \\
\hline & GT & GS & $(\mathrm{GT}+\mathrm{GS})$ & $\mathrm{T}$ & $S$ & G \\
\hline Sample 01_Mz_BR & 12.50 & 2.27 & 14.77 & 21.59 & 5.68 & 39.77 \\
\hline Sample 02_Mz_BR & 13.64 & 3.41 & 17.05 & 26.14 & 4.55 & 40.91 \\
\hline Sample 06_Mz_BR & 14.77 & 3.41 & 18.18 & 26.14 & 4.55 & 42.05 \\
\hline HQ439439_Mz_BR & 12.50 & 3.41 & 15.91 & 21.59 & 4.55 & 42.05 \\
\hline HQ439440_Mz_BR & 12.50 & 3.41 & 15.91 & 22.73 & 5.68 & 40.91 \\
\hline HQ342698_Mz_BR & 8.43 & 8.43 & 16.87 & 22.89 & 12.05 & 37.35 \\
\hline Sample $08 \_$Sr_BR & 13.64 & 3.41 & 17.05 & 23.86 & 4.55 & 40.91 \\
\hline Sample 09_Sr_BR & 12.50 & 1.14 & 13.64 & 22.73 & 5.68 & 36.36 \\
\hline Sample 10_Sr_BR & 12.50 & 2.27 & 14.77 & 21.59 & 5.68 & 39.77 \\
\hline Sample 11_Sr_BR & 12.50 & 2.27 & 14.77 & 21.59 & 5.68 & 39.77 \\
\hline Sample13_Sr_BR & 14.77 & 3.41 & 18.18 & 26.14 & 4.55 & 42.05 \\
\hline Sample 14_Sr_BR & 10.23 & 3.41 & 13.64 & 19.32 & 4.55 & 38.64 \\
\hline D00949_MDB_Mz_US & 9.09 & 11.36 & 20.45 & 18.18 & 14.77 & 35.23 \\
\hline A34976_MDB_MZ_US & 9.09 & 11.36 & 20.45 & 18.18 & 14.77 & 35.23 \\
\hline GU474635_Mz_MX̄ & 9.09 & 11.36 & 20.45 & 15.91 & 18.18 & 36.36 \\
\hline AY195610_Mz_MX & 8.22 & 9.59 & 17.81 & 13.70 & 17.81 & 31.51 \\
\hline DQ647659_Mz_TH & 6.85 & 5.48 & 12.33 & 9.59 & 6.85 & 43.84 \\
\hline DQ925429_Mz_VN & 6.85 & 8.22 & 15.07 & 9.59 & 12.33 & 46.58 \\
\hline AM110759_Mz_ES & 4.11 & 10.96 & 15.07 & 6.85 & 23.29 & 34.25 \\
\hline X98169_Mz_DE & 4.11 & 10.96 & 15.07 & 6.85 & 23.29 & 34.25 \\
\hline X98168_Mz_DE & 4.11 & 10.96 & 15.07 & 8.22 & 23.29 & 34.25 \\
\hline X98167 Mz DE & 4.11 & 10.96 & 15.07 & 9.59 & 21.92 & 32.88 \\
\hline DQ973170_Mz_AR & 5.48 & 9.59 & 15.07 & 8.22 & 19.18 & 35.62 \\
\hline AY569692_Mz_CN & 8.22 & 8.22 & 16.44 & 15.07 & 16.44 & 35.62 \\
\hline AY149118_Mz_CN & 6.85 & 9.59 & 16.44 & 13.70 & 17.81 & 34.25 \\
\hline AJ310104_Sgc_CN & 5.48 & 8.22 & 13.70 & 16.44 & 13.70 & 34.25 \\
\hline $\mathrm{AJ} 310103 \mathrm{Sgc} C \mathrm{CN}$ & 2.74 & 8.22 & 10.96 & 16.44 & 12.33 & 32.88 \\
\hline AJ310102_Sgc_CN & 2.74 & 8.22 & 10.96 & 15.07 & 12.33 & 32.88 \\
\hline AY819716_Sgc_BR & 4.11 & 0.00 & 4.11 & 13.70 & 1.37 & 30.14 \\
\hline AY819717_Sgc_BR & 4.05 & 1.35 & 5.41 & 14.86 & 1.35 & 31.08 \\
\hline AY819718 Sgc BR & 2.74 & 1.37 & 4.11 & 15.07 & 1.37 & 31.51 \\
\hline AY819719 Sgc BR & 4.55 & 0.00 & 4.55 & 13.64 & 0.00 & 30.30 \\
\hline D00948 Sgc AU & 4.11 & 2.74 & 6.85 & 13.70 & 2.74 & 32.88 \\
\hline U57354_Sgc_US & 3.08 & 1.54 & 4.62 & 12.31 & 1.54 & 30.77 \\
\hline U57356_Sgc_US & 4.35 & 1.45 & 5.80 & 13.04 & 1.45 & 33.33 \\
\hline U57355_Sgc US & 4.35 & 2.90 & 7.25 & 13.04 & 2.90 & 31.88 \\
\hline EU196423_Sgc_AR & 2.74 & 2.74 & 5.48 & 12.33 & 2.74 & 31.51 \\
\hline EU196429_Sgc_AR & 2.74 & 2.74 & 5.48 & 12.33 & 2.74 & 31.51 \\
\hline DQ438949_Sgc_IR & 2.74 & 2.74 & 5.48 & 13.70 & 2.74 & 30.14 \\
\hline Average & 7.36 & 5.46 & 12.83 & 16.04 & 9.15 & 35.78 \\
\hline
\end{tabular}




\section{Phylogenetic analysis}

For the phylogenetic reconstruction we used 281 sequences in total, which included 275 SCMV, selected from NCBI as described above, and six outgroup sequences: MDMV-A(U07216), MDMV from Argentina (DQ973169), JGMV (U072170), SrMV (U57358), PenMV (AY642590), and ZeMV (AF228693) (Figure 2). The tree was fully resolved and no polytomies were observed in the main nodes (thicker lines, Figure 2). According to the topology of the phylogenetic tree, SCMV sequences clustered in five distinct monophyletic groups. Group I containing sugarcane isolates from China and Vietnam, and based on the outgroup, this group is placed in the basal position in relation to the four other groups. The remaining four groups were all derived from the same node, which further branched in the nodes that originates the last common ancestor of the groups II, III, IV, and V, respectively. Bootstrap support was higher than $95 \%$ for all the main nodes, except for the node of the last common ancestor for groups III A and III B (71\%). Group II-subgroup II A-comprised maize isolates from USA and Mexico, and subgroup II B, which was formed by sugarcane and maize isolates from Thailand and Vietnam, Group III-subgroup III A, composed of sugarcane isolates from China and subgroup III B composed by maize isolates from different countries, Group IV, consisting of the maize and sorghum isolates from Brazil, and Group V, consisting of the sugarcane isolates from several countries.

The phylogenetic analysis of the SCMV based on CP nucleotide sequences showed that the Brazilian maize and sorghum isolates and the Brazilian maize accessions from the GenBank, HQ342698, HQ439439, and HQ439440, were clustered as a monophyletic group, comprising only these isolates, while Brazilian accessions having sugarcane as host (AY819716, AY819717, AY819718, and AY819719) were grouped in a different cluster (Group V).

\section{Discussion}

Positive serological reactions with SCMV (MDMV B) and SCMV-Argentina confirmed the SCMV as the potyvirus infecting maize and sorghum Brazilian samples. The weak reaction of these samples with the antibody against SCMV-USA suggests differences between this virus and the SCMV from Brazil. Although some weak reaction with the JGMV and MDMV-A for some tested samples has been verified, these results evidence the presence of cross reactivity among these viruses, thereby limiting the use of serological tests for identification of these potyvirus species in maize and sorghum. This may be due to the polyclonal nature of the antibodies. Cross-reactions occasionally occur between organisms taxonomically related as potyviruses (Berger et al., 2005). Also, the RT-PCR analysis, with specific primers for SCMV, confirmed the presence of this virus in maize and sorghum in Brazil. SCMV potyviruses in maize have also been confirmed in Brazil in other studies (Melo, 2000; Resende et al., 2004; Souza et al., 2008; Gonçalves et al., 2011). Shukla et al. (1992) mention that serological relationships among members of the family Potyviridiae are complex and inconsistent. However, the coat protein $(\mathrm{CP})$ sequence of potyviruses can be used to differentiate between individual potyviruses and their strains (Shukla et al. 1992). According to the International Committee on Taxonomy of Viruses (ICTV), a CP aa sequence identity less than $80 \%$ is one of the molecular criteria for species demarcation in the genus (Berger et al., 2005); Also, 
Adams et al. (2005) verified that $76-77 \%$ nt identity was the optimal species demarcation criterion for the $\mathrm{CP}$ and $82 \%$ aa identity would reliably distinguish between most species. The N-terminal of the CP of distinct potyviruses is highly variable, whereas the C-terminal is most conserved (Ward \& Shukla, 1991), suggesting that the N-terminal is involved in the virus-specific function or interaction of the virus with a host (Riechmann et al., 1992).

Considering the entire nucleotide $\mathrm{CP}$ sequence, the Brazilian samples showed the highest identities, 87 to $96 \%$ and 85 to $87 \%$, respectively, with the Brazilian accessions having maize as host and with the SCMV-MDB D00949, A34976, and GU474635. These results are in agreement with the studies from Melo (2000), which showed high nucleotide $(86.2 \%)$ and amino acid (88.8\%) similarities with the MDMV-B strain, belonging to the SCMV species, reporting that it could be the principal potyvirus in Brazil. Comparisons of the conserved core region of the CP gene showed identities ranging from 94 to $99 \%$, between the Brazilian field isolates and the SCMV accessions from GenBank, used for comparisons (Figure 1). Oertel et al. (1997) also mention homology higher than $92 \%$, using comparisons of the SCMV core region of the $\mathrm{CP}$ and it matched with those verified between strains of the same potyvirus.

The N-terminal of the Brazilian maize and sorghum isolates presented fifteen amino acids longer than the majority of the accessions from GenBank used for comparisons, except for the SCMV-MDBs from the USA and the isolate from Mexico, which had the same size (Figure 1). This difference in size could be explained by the repeated and partial repeated dodecapeptide. Comparing the predominant repeated sequence in the CP N-terminal among the Brazilian field isolates and that in the SCMV-MDB from the
USA (Frenkel et al., 1991) (Figure 1), the frequent change of an $\mathrm{S}$ (serine) to a $\mathrm{T}$ (threonine) amino acid is evident. Both amino acids present a polar, uncharged R group (Lehninger et al., 1993). Kimalov et al. (2004) suggested that maintenance of the CP N-terminal net charge was essential for ZYMV infectivity and not the primary sequence. The sequencing repeat of the Brazilian maize and sorghum isolates, GTGTGATGGQAG, and the putative Q/S cleavage site between Nib/CP differ from the sugarcane Brazilian accessions from GenBank, AY819716 to AY819719, showing, respectively, QPPATGAAAQ and -/A (Figure 1). Gonçalves et al. (2007b) mention that the sugarcane accession AY819719, when compared with the SCMV isolates from the GenBank presented the highest identity, 94 to $96 \%$, to sugarcane isolates from Australia and the USA.

The N-terminal sequence of Brazilian isolates, fifteen amino acids longer than the majority of the SCMV, a different repeated sequence, and a higher content of the GT dipeptide (Figure 1, Table 2), could explain the classification of the Brazilian isolates in a different group (Figure 2), suggesting a new SCMV strain. These differences in CP protein sequence and separation of the maize and sorghum field isolates from sugarcane Brazilian accessions in the phylogenetic tree (Figure 2) suggest the existence of different strains of the SCMV in Brazil.

Phylogenetic analysis showed some correlation between the phylogenetic groups and the geographical origin of the SCMV isolates that could be seen in the groups or subgroups (Figure 2): Group I comprising China and Vietnam, Group II A formed by the USA and Mexico, Group II B containing Thailand and Vietnam, III A represented by China, and Group IV, by Brazil. Also, separation by host was verified in some groups or subgroups: Group I 


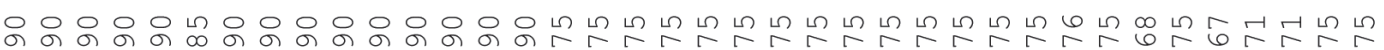

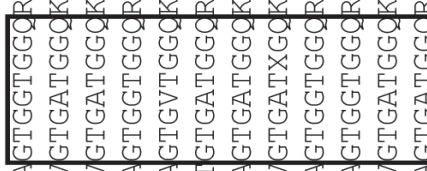

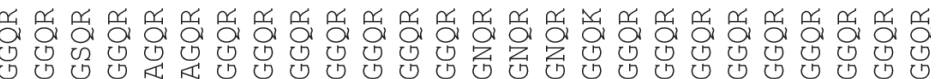

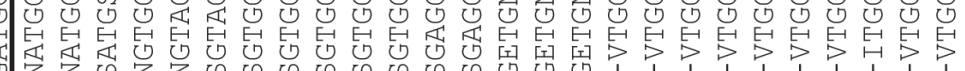

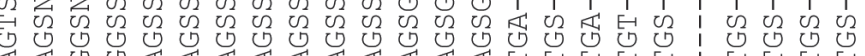

N

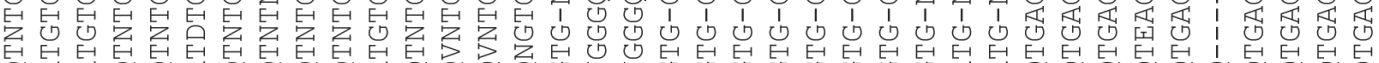

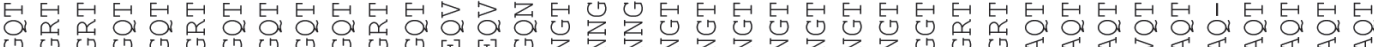

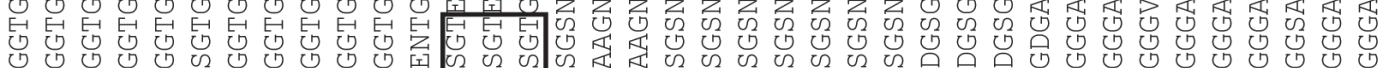

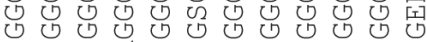
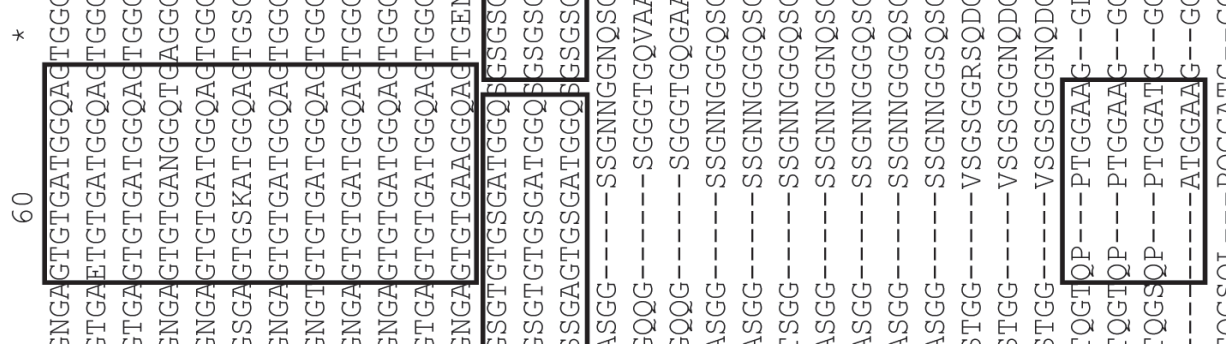

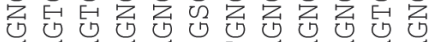

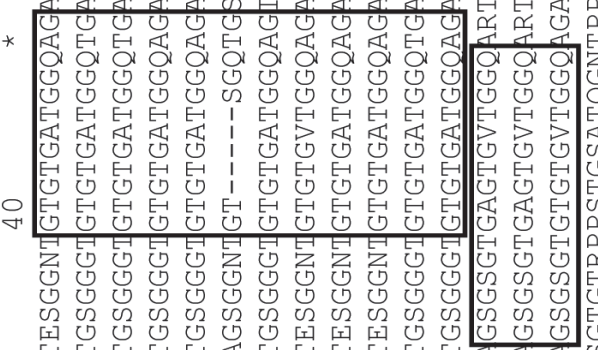

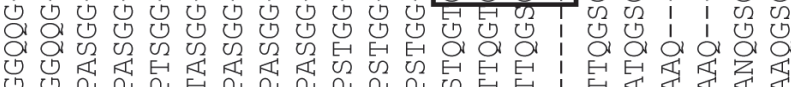

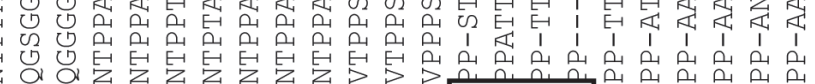

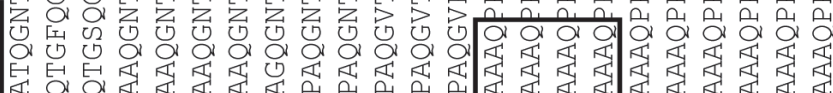

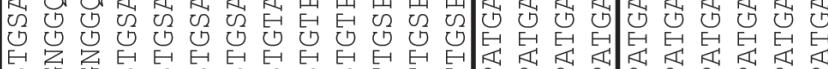

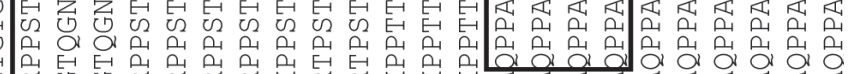

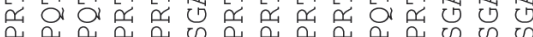

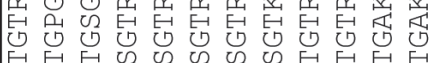

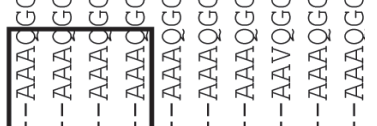

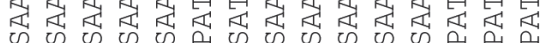

की

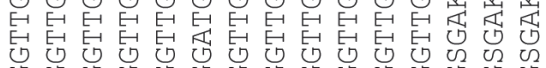

凹

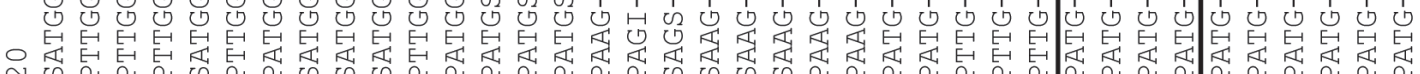
जथ

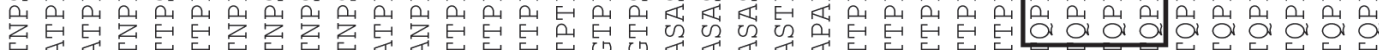

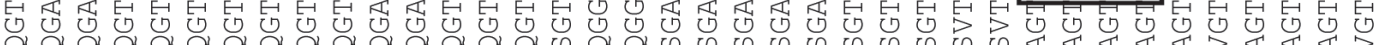

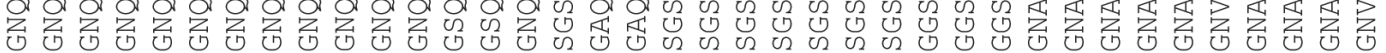

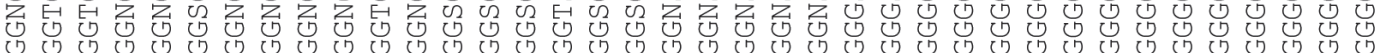

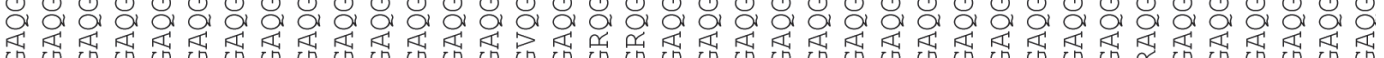

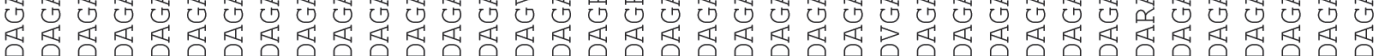

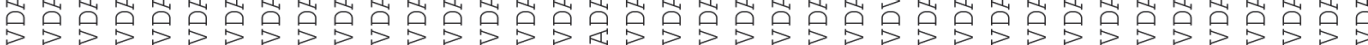

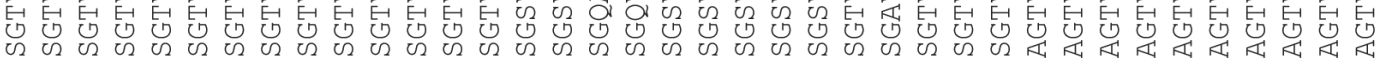

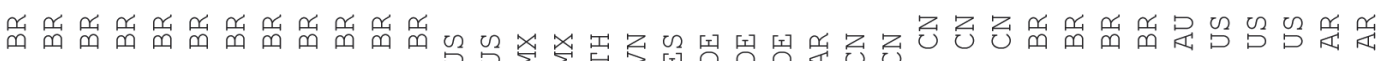

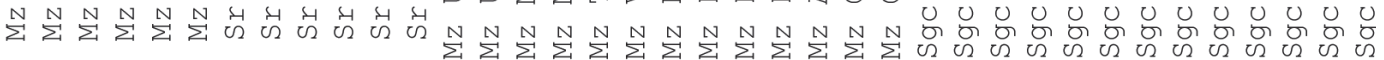

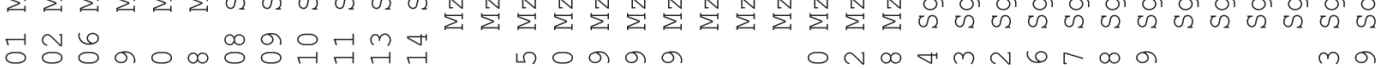

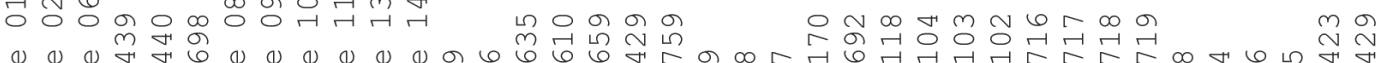

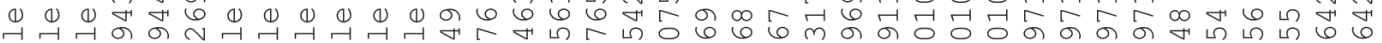

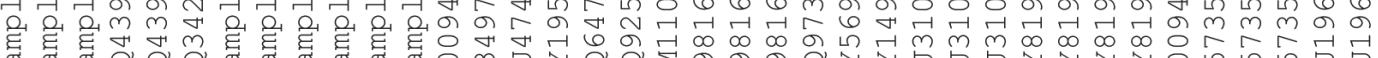

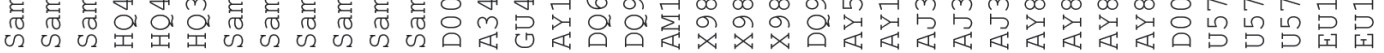

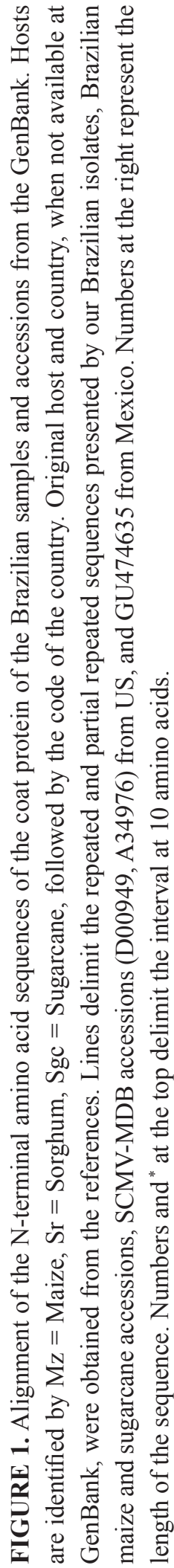

Revista Brasileira de Milho e Sorgo, v.11, n.2, p. 120-136, 2012

Versão impressa ISSN 1676-689X / Versão on line ISSN 1980-6477 - http://www.abms.org.br 


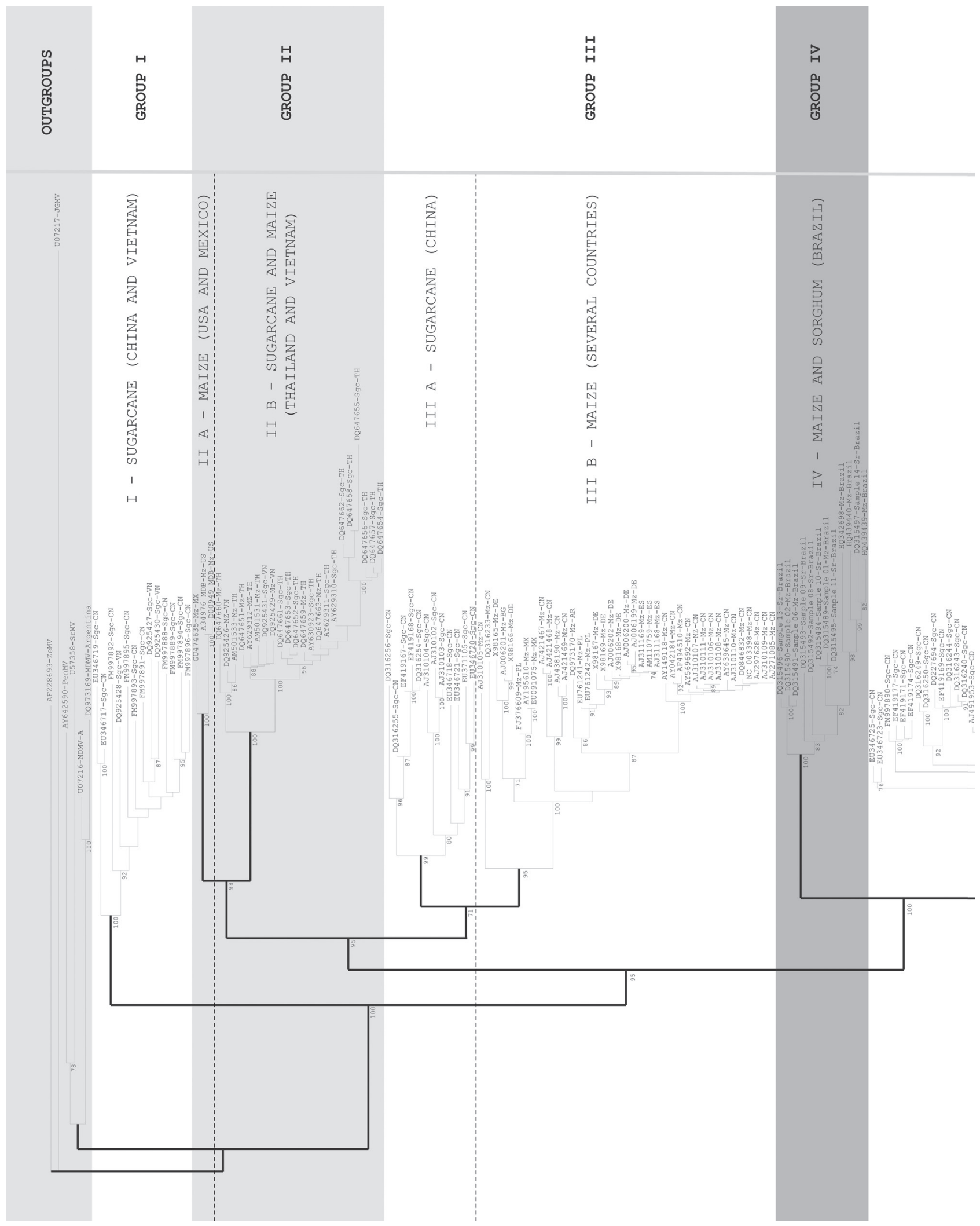




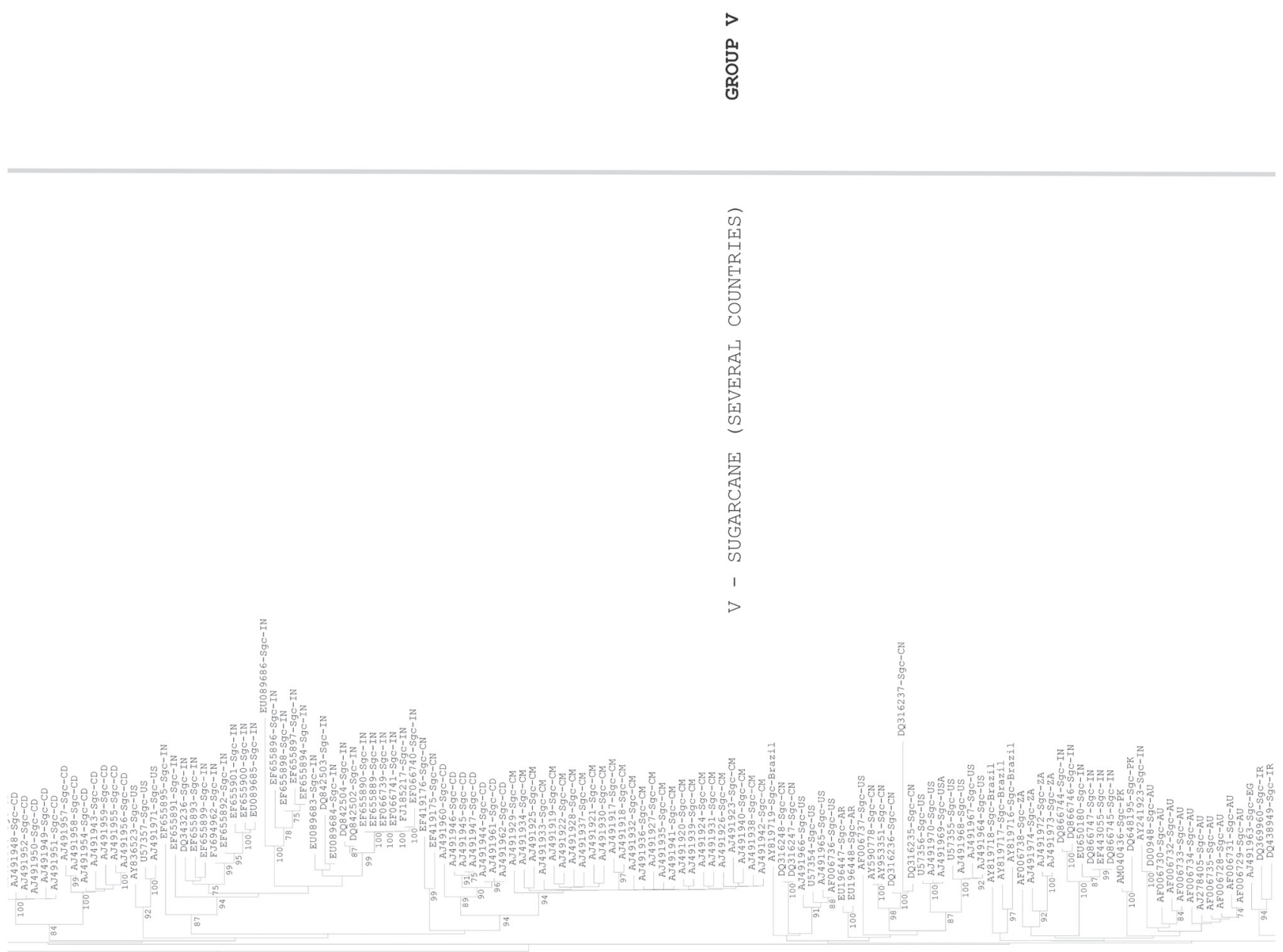

Revista Brasileira de Milho e Sorgo, v.11, n.2, p. 120-136, 2012

Versão impressa ISSN 1676-689X / Versão on line ISSN 1980-6477 - http://www.abms.org.br 

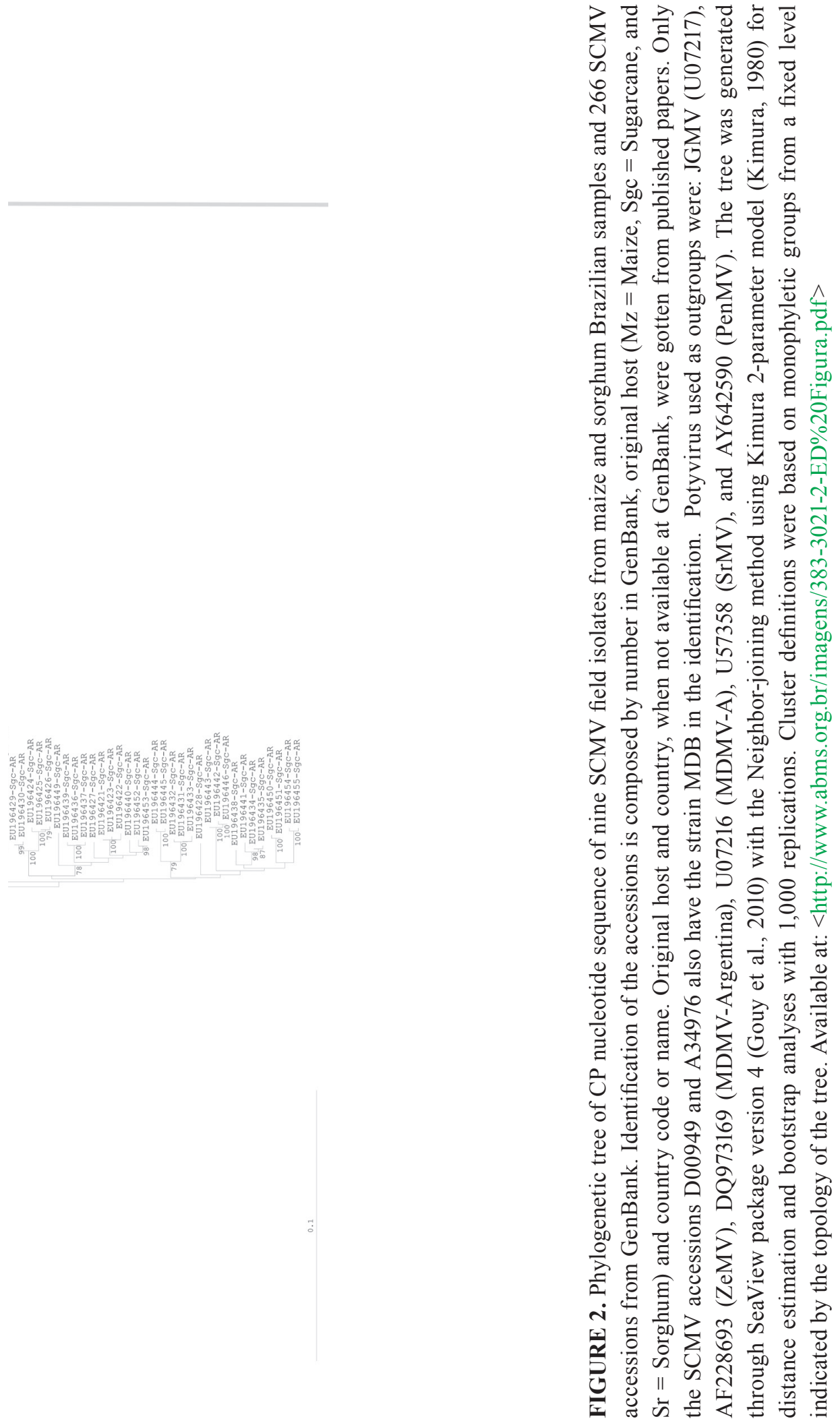
sugarcane, Group II A maize, Group III A sugarcane, Group III B maize, and Group V sugarcane. Correlations between SCMV phylogenetic groups and geographical origin were also found by Alegria et al. (2003). In addition, an interesting pattern emerged from our phylogenetic analysis, apart from Group I, which is basal in relation to the other groups and is composed exclusively by SCMV sequences obtained from sugarcane; the other groups are composed of monophyletic clusters formed either by sequences of maize or sugarcane only, which were derived from the same last common ancestor. The Group II B is the only cluster possessing sequences of both hosts (maize and sugarcane). Moreover, each of these pairs of clusters had the same last common ancestor (Figure 2).

Sequencing and phylogenetic analysis have shown that the SCMV of maize and sorghum from Brazil constitute a distinct monophyletic group in relation to SCMV from several geographic regions of the world, including the SCMV from Brazilian sugarcane accessions retrieved from GenBank. This genetic difference can possibly be attributed to the virus evolution on a wide range of hosts in Brazil, provided by many weed and cultivated species growing throughout the year and a great diversity of aphid species-vectors, conditions that predominate in tropical and subtropical areas.

Our results showed the Brazilian maize and sorghum isolates forming a monophyletic group and these findings were in agreement with other studies using our sequences, already deposited in the GenBank (Ha et al., 2008; Xu et al., 2008; Gao et al., 2011). These results suggest and reinforce our findings towards a new SCMV strain. Further, studies using potyvirus $\mathrm{CP}$ gene sequencing from Brazilian sorghum isolates have here been reported for the first time.

\section{Acknowledgements}

The authors thank the CNPq/Prosul for partial financial support for this research. We thank Célio Ramos das Neves for the help with the field and lab works.

\section{References}

ADAMS, M. J.,; ANTONIW, J. F.; FAUQUET, C. M. Molecular criteria for genus and species discrimination within the family Potyviridae. Archives of Virology, New York, v. 150, p. 459-479, 2005.

ALEGRIA, O. M.; ROYER, M.; BOUSALEM, M.; CHATENET, M.; PETERSCHMITT, M.; GIRARD, J. C.; ROTT, P. Genetic diversity in the coat protein coding region of eighty-six Sugarcane mosaic virus isolates from eight countries, particularly from Cameroom and Congo. Archives of Virology, New York, v. 148, p. 357-372, 2003.

ALMEIDA, A. C. L.; OLIVEIRA E.; RESENDE R. Detecção de vírus por RT-PCR, hibridação "dotblot" e dot-ELISA em milho com mosaico-comum. Fitopatologia Brasileira, Brasília, DF, v. 25, p. 168170, 2000.

ALMEIDA, A. C. L.; OLIVEIRA, E.; RESENDE, R. O. Fatores relacionados à incidência e disseminação do vírus do mosaico comum do milho. Fitopatologia Brasileira, Brasília, DF, v. 6, n. 4, p. 766-769, 2001. ALTSCHUL, S. F.; GISH, W.; MILLER, W.; MYERS, E. W.; LIPMAN, D. J. Basic local alignment search tool. Journal of Molecular Biology, London, v. 215, p. 403-410, 1990.

BERGER, P. H.; ADAMS, M. J.; BARNETT, O. W.; BRUNT, A. A.; HAMMOND, J.; HILL, J. H.; JORDAN, R. L.; KASHIWAZAKI, S.; RYBICKI, E.; SPENCE, N.; STENGER, D. C.;OHKI, S.T.; UYEDA, 
I.; ZAAYEN, A. VAN; VALKONEN, J.; VETTEN,

H. J. Family Potyviridae. In: FAUQUET, C. M.; MAYO, M. A.; MANILOFF , J.; DESSELBERGER, U.; BALL, L. A. (Ed.). Virus Taxonomy. London: Academic Press, 2005. p. 819-841. CLARK, M. F.; ADAMS, N. A. Characteristic of the microplate method of enzyme-linked imunosorbent assay for the detection of plant viruses. Journal of General Virology, Cambridge, v. 34, p. 475-483, 1977. CRUZ, J. C.; SILVA, G. H.; PEREIRA FILHO, I. A.; GONTIJO NETO, M. M.; GUIMARÃES, P. C. Caracterização do cultivo de milho safrinha de alta produtividade em 2008 e 2009. Revista Brasileira de Milho eSorgo, Sete Lagoas, v. 9, n. 2, p. 177-188, 2010. DENG, C. L.; WANG, W. J.; WANG, Z. Y.; JIANG, X.; CAO, Y.; ZHOU, T.; WANG, F. R.; LI, H. F.; FAN, Z. F. The genomic sequence and biological properties of Pennisetum mosaic virus, a novel monocot-infecting potyvirus. Archives of Virology, New York, v. 153, p. 921-927, 2008.

EDWARDSON, J. R.; CHRISTIE, R. G. The potyvirus group. Gainsville: Florida Agricultural Experiment Station, 1991. (Monograph 16).

FRENKEL, M. J.; JILKA, J. M.; MCKERN, N. M.; STRIKE, P. M.; CLARK JR., J. M.; SHUKLA, D. D. Unexpected sequence diversity in the amino-terminal ends of the coat proteins of strains of sugarcane mosaic virus. Journal of General Virology, Amsterdam, v. 72, p. 237-242, 1991.

GAO, B.; CUI, X-W.; LI, X. D.; ZHANG, C. Q. Complete genomic sequence analysis of a highly virulent isolate revealed a novel strain of Sugarcane mosaic virus. Virus Genes, Norwell, v. 43, p. 390-397, 2011.

GIOLITTI, F.; HERRERA, M. G.; MADARIAGA, M.; LENARDON, S. L. Detection of Maize dwarf mosaic virus (MDMV) on maize in Chile. Maydica,
Bergamo, v. 50, p. 101-104, 2005.

GONÇALVES, M. C.; GALDEANO, M. D.; MAIA, I. G.; CHAGAS, C. M. Variabilidade genética de Sugarcane mosaic virus, causando mosaico em milho no Brasil. Pesquisa Agropecuária Brasileira, Brasília, DF, v. 46, p. 362-369, 2001.

GONÇALVES, M. C.; MAIA, I. G.; GALLETI, S. R.; FANTIN, G. M. Infecção mista pelo Sugarcane mosaic virus e Maize rayado fino virus provoca danos na cultura do milho no estado de São Paulo. Summa Phytopathologica, Piracicaba, v. 33, n. 4, p. 348352, $2007 \mathrm{a}$.

GONÇALVES, M. C.; SANTOS, A. M.; MAIA, I. G.; CHAGAS, C. M.; HARAKAWA, R. Caracterização de um isolado de sugarcane mosaic virus que quebra a resistência de variedades comerciais de cana-deaçucar. Fitopatologia Brasileira, Brasília, DF, v. 32, n. 1, p. 32-39, $2007 \mathrm{~b}$.

GOUY, M.; GUINDON, S.; GASCUEL, O. SeaView version 4 : a multiplatform graphical user interface for sequence alignment and phylogenetic tree building. Molecular Biology and Evolution, Chicago, v. 27, n. 2, p. 221-224, 2010. HA, C.; REVILL, P.; HARDING, R. M.; VU, M.; DALE, J. L. Identification and sequence analysis of potyviruses infecting crops in Vietnam. Archives of Virology, New York, v. 153, p. 45-60, 2008.

KIMALOV, B.; GAL-ON, A.; STAV, R.; BELAUSOV, E.; ARAZI, T. Maintenance of coat protein N-terminal net charge and not primary sequence is essential for zucchini yellow mosaic vírus systemic infectivity. Journal of General Virology, Amsterdam, v. 85, p. 3421-3430, 2004.

KIMURA, M. A simple method for estimating evolutionary rates of base substitutions through comparative studies of nucleotide sequences. Journal of Molecular Evolution, New York, v. 16, 
p. $111-120,1980$.

LARKIN, M. A.; BLACKSHIELDS, G.; BROWN, N. P.; CHENNA, R.; MCGETTIGAN, P. A.; MCWILLIAM, H.; VALENTIN, F.; WALLACE, I. M.; WILM, A.; LOPEZ, R.; THOMPSON, J. D.; GIBSON, T. J.; HIGGINS, D. G. Clustal W and Clustal X version 2.0. Bioinformatics, Oxford, v. 23, n. 21, p. 2947-2948, 2007.

LEHNINGER,A.L.;NELSON,D.L.;COX,M.M.Principles of Biochemistry. 2nd ed. New York: Worth, 1993. LENARDON, S. L.; GIOLITTI, F. Virus del Mosaico Enanizante del Maíz. In: DOCAMPO, D. M.; LENARDÓN, S. L. (Ed.). Métodos para detectar patógenos sistémicos. Córdoba:Argentina, 1999.p. 99

LENARDON, S. L.; GIOLITTI, F. Maize Argentina mosaic. In: LAPIERRE, H.; SIGNORET, P. A (Ed.). Viruses and virus diseases of Poaceae (Gramineae). Montpellier: INRA, 2004. p. 635-636. MELO, P. R. Estudo da variabilidade e do uso de métodos moleculares na detecção dos vírus do rayado fino e do mosaico comum do milho (Zea mays L.) 2000.104 f. Tese (Mestrado) - Universidade de Brasília, Brasília, DF.

MELO, P. R.; OLIVEIRA, E.; RESENDE, R. O. Virose do mosaico comum do milho no Brasil: caracterização e incidência. Fitopatologia Brasileira, Brasília, DF, v. 25, p. 444-445, 2000.

OERTEL, U.; SCHUBERT, J.; FUCHS, E. Sequence comparison of the 3'-terminal parts of the RNA of four German isolates of sugarcane mosaic potyvirus (SCMV). Archives of Virology, New York, v. 142, p. 675-687, 1997.

RESENDE, R. O.; ALMEIDA, A. C. L.; MELO, P. R. Técnicas moleculares para detecção de vírus em milho e em insetos-vetores. In: OLIVEIRA, E.; OLIVEIRA, C. M. (Ed.). Doenças em milho: molicutes, vírus, vetores, mancha por Phaeosphaeria. Brasília, DF:
Embrapa Informação Tecnológica, 2004. p. 206-226.

RIECHMANN, J. L.; LAIN, S.; GARCIA, J. A. Highlights and prospects of potyvirus molecular biology. Journal of General Virology, Amsterdam, v. 73, p.1-16, 1992.

ROWHANI, A.; MANINGAS, M. A.; LILE, L.; DAUBERT, S. D.; GOLINO, D. A. Development of a detection system for viruses of woody plants based on PCR analysis of immobilized virions. Phytopathology, St.Paul, v. 85, p. 347-352, 1995.

SHEIFERS, D. L.; SALOMON, R.; MARIE-JEANNE, V.; ALLIOT, B.; SIGNORET, P.; HABER, S.; LOBODA, A.; ENS, W.; SHE, Y. M.; STANDING, K. G. Characterization of a novel potyvirus isolated from maize in Israel. Phytopathology, St.Paul, v. 90, p. 505-513, 2000.

SHUKLA, D. D.; LAURICELLA, R.; WARD, C. W. Serology of potyviruses: current problemas and some solutions. Archives of Virology, New York, v. 5, p57-59, 1992. Suplemento

SHUKLA, D. D.; FRENKEL, M. J.; WARD, C. W. Structure and function of the potyvirus genome with special reference to the coat protein coding region. Canadian Journal of Plant Pathology, Ottawa, v. 13, p. 178-191, 1991.

SHUKLA, D. D.; WARD, C. W.; Brunt, A. A. The Potyviridae. Wallingford: CAB International, 1994. $516 \mathrm{p}$.

SHUKLA, D. D.; WARD, C. W. Amino acid sequence homology of coat proteins as a basis for identification and classification of the potyvirus group. Journal of General Virology, Amsterdam, v. 69, p. 2703-2710, 1988.

SHUKLA, D. D.; WARD, C. W. Identification and classification of potyviruses on the basis of coat protein sequence data and serology. 
Archives of Virology, New York, v. 106, p. 171-200, 1989.

SOUZA, I. R. P.; LENARDON, S.; GIOLITTI, F. J.; OLIVEIRA, E.; CARNEIRO, N. P.; GOMES, E. A. Identification of the potyvirus species in maize, sorghum and sugarcane from Brazil. In: CONGRESSO BRASILEIRO DE GENÉTICA, 51., 2005, Águas de Lindóia. Resumos... Águas de Lindóia: SBG, 2005. p. 64.

SOUZA, I. R. P.; SCHUELTER,A. R.; GUIMARÃES, C. T.; CHUSTER, I.; OLIVEIRA, E. de; REDINBAUGH, M. Mapping QTL contributing to SCMV resistance in tropical maize. Hereditas, Lund, v. 145, p. 167$173,2008$.

SUEHIRO, N.; MATSUDA, K.; OKUDA, S.; NATSUAKI,

T. Simplified method for obtaining plant viral
RNA for RT-PCR. Journal of Virology Methods, Amsterdam, v. 125, p. 67-73, 2005.

WAQUIL, J.; OLIVEIRA, E.; PINTO, N. F. J. A.; FERNANDES, F. T.; CORRÊA, L. A. Efeito na produção e incidência de viroses em híbridos comerciais de milho. Fitopatologia Brasileira, Brasília, DF, v. 41, n. 4, p. 460$463,1996$.

WARD, C. W.; SHUKLA, D. D. Taxonomy of potyviruses: current problems and some solutions. Intervirology, v. 32 , p. 269-296, 1991.

XU, D. L.; PARK, J. W.; MIRKOV, T. E. Viruses causing mosaic disease in sugarcane and their genetic diversity in Southern China. Archives of Virology, New York, v. 153, p. 1031-1039, 2008. 